\title{
PENINGKATKAN PRESTASI BELAJAR SISWA PADA MATERI APLIKASI FUNGSI MELALUI METODE PENEMUAN TERBIMBING
}

\author{
* Imadiah \\ * Imadiah adalah Guru SMA Negeri 14 Banda Aceh \\ Email : imadiahsulaiman@gmail.com
}

\begin{abstract}
Abstrak
Salah satu keberhasilan dalam proses belajar mengajar adalah kemampuan guru dalam merancang PBM, melaksanakan pembelajaran dan mengevaluasi pembelajaran. Guru juga harus mampu dalam memilih dan menerapkan metode yang sesuai dengan materi yang akan di ajarkan. Penelitian ini berdasarkan pada rumusan permasalahan: apakah prestasi belajar siswa kelas XI MIPA-1 SMA Negeri 14 Banda Aceh pada materi aplikasi turunan fungsi dapat ditingkatkan dengan penggunaan metode pembelajaran penemuan terbimbing? Tujuan dalam penelitian ini adalah:untuk mengetahui peningkatan prestasi belajar siswa pada materi aplikasi turunan fungsi dengan metode pembelajaran penemuan terbimbing di kelas XI MIPA-1 SMA Negeri 14 Banda Aceh. Objek dalam penelitian ini adalah siswa kelas XI MIPA -1. Pengumpulan data dilakukan melalui tes hasil belajar dengan perlakuan dua siklus. Analisis data dilakukan dengan diskriptif kualitatif dan kuantitatif. Hasil penelitian menunjukkan bahwa penggunaan metode pembelajaran penemuan terbimbing dapat meningkatkan prestasi belajar siswa pada materi aplikasi turunan fungsi. Hal ini ditandai dengan peningkatan ketuntasan belajar siswa dalam setiap siklus, yaitu siklus I (53\%) dan siklus II (87,5\%).
\end{abstract}

Kata Kunci : Penemuan Terbimbing, Prestasi Belajar Siswa, Materi Aplikasi Turunan Fungsi.

\section{PENDAHULUAN}

Penguasaan matematika oleh peserta didik bertujuan untuk membangun kemampuan berpikir logis, analitis, sistematis, kritis, dan kreatif, serta kemampuan bekerjasama. Kompetensi tersebut diperlukan agar peserta didik dapat memiliki kemampuan memperoleh, mengelola, dan memanfaatkan informasi untuk bertahan hidup pada keadaan yang selalu berubah, tidak pasti, dan kompetitif.

Dalam pembelajaran matematika, sering ditemukan permasalahan dalam proses dan hasil belajar peserta didik. Adapun permasalahan tersebut antara lain penguasaan materi pelajaran matematika yang masih sangat rendah, mata pelajaran Matematika dimata para siswa merupakan salah satu mata pelajaran yang menjadi momok menakutkan, mereka mengikuti pembelajaran matematika hanya karena tuntutan yang harus dijalani sebagai seorang siswa, akibatnya nilai ujian peserta didik rendah sehingga prestasi belajar siswa juga rendah. 
Hal ini merupakan tantangan bagi guru matematika untuk mencari solusi bagaimana kegiatan pembelajaran menjadi bermakna dan tidak menyeramkan bagi siswa. Guru harus berusaha menentukan pendekatan, model dan metode yang tepat agar materi yang disajikan dapat dimengerti dan dipahami serta para siswa tahu kegunaan materi tersebut dalam kehidupan sehari-hari.

Efektif tidaknya sebuah proses pembelajaran sangat tergantung kepada rancangan pembelajaran yang disusun oleh guru. Rancangan pembelajaran yang baik adalah rancangan pembelajaran yang mengandung strategi yang dapat memungkinkan peserta didik berperan aktif melakukan kegiatan belajar melalui berbagai pengalaman belajar, baik secara fisik maupun mental. Dari pengalaman belajar tersebut mendorong perubahan pada diri peserta didik baik dari aspek kognitif, afektif maupun psikomotrik. Salah satu strategi yang bisa diterapkan agar para peserta didik dapat berperan aktif mengikuti proses pembelajaran adalah dengan menggunakan metode pembelajaran penemuan terbimbing..

Menurut Bruner (Dahar, 1996), metode pembelajaran penemuan terbimbing adalah sesuai dengan pencarian pengetahuan secara aktif oleh manusia. Disini peserta didik tidak hanya berusaha sendiri untuk mencari pemecahan masalah serta pengetahuan yang menyertainya, namun menghasilkan pengetahuan yang benar-benar bermakna bagi mereka. Dalam metode penemuan terbimbing, guru juga berperan sebagai fasilitator yang membimbing siswa melalui pertanyaan-pertanyaan yang mengarahkan siswa untuk menghubungkan pengetahuan yang lalu dengan pengetahuan yang sedang ia peroleh. Siswa didorong untuk berpikir sendiri, menganalisis sendiri, sehingga dapat menemukan konsep, prinsip, ataupun prosedur berdasarkan bahan ajar yang telah disediakan guru.

Adapun yang menjadi tujuan dalam penelitian ini adalah untuk mengetahui peningkatan prestasi belajar siswa pada materi aplikasi turunan fungsi dengan metode pembelajaran penemuan terbimbing di kelas XI MIPA-1 SMA Negeri 14 Banda Aceh.

Slameto (2003) menyatakan bahwa belajar adalah suatu usaha yang dilakukan seseorang untuk memperoleh suatu perubahan tingkah laku sebagai hasil pengalaman sendiri dalam interaksinya dengan lingkungan.

Dalam proses belajar mengajar prestasi belajar merupakan cerminan capaian tingkat penguasaaan materi oleh siswa yang diperoleh dari proses pengukuran. Menurut Kamus besar Bahasa Indonesia (2001), prestasi belajar adalah penguasaan pengetahuan atau 
keterampilan yang dikembangkan oleh mata pelajaran, lazimnya ditunjukkan dengan nilai tes atau angka nilai yang diberikan oleh guru.

Dapat disimpulkan bahwa prestasi belajar adalah hasil belajar yang dicapai oleh siswa dalam proses belajar mengajar yang ditunjukkan dengan angka nilai tes yang diberikan oleh guru. Menurut Sutrisno (2007), prestasi belajar dipengaruhi oleh dua faktor, yaitu faktor yang berasal dari dalam individu (internal) dan faktor yang berasal dari luar (eksternal) diri individu. Faktor internal yang mempengaruhi proses dan hasil belajar antara lain: pemahaman siswa terhadap hasil belajar, minat siswa terhadap hasil belajar, kesehatan siswa, kesehatan siswa, kecakapan siswa dalam pelajaran, kebiasaan belajar, intelegensi, bakat dan penguasaan bahasa. Faktor-faktor eksternal yang mempengaruhi proses dan hasil belajar adalah faktor yang bersumber dari: sekolah, keluarga dan masyarakat.

Inqury dalam bahasa Indonesia berarti penemuan. Menurut Sund (dalam Suryobroto, 2002) dinyatakan bahwa metode pembelajaran penemuan terbimbing adalah proses mental dimana siswa mengasimilasikan sesuatu konsep atau sesuatu prinsip. Proses mental tersebut misalnya: mengamati, menggolong-golongkan, membuat dugaan, menjelaskan, mengukur, membuat kesimpulan, dan sebagainya. Yang dimaksud dengan konsep misalnya: segitiga, demokrasi, panas, energi, dan sebagainya. Sedangkan prinsip misalnya: logam apabila dipanasi mengembang, lingkungan berpengaruh terhadap kehidupan organisme, dan sebagainya.

Menurut Hudojo (2003) berpendapat bahwa metode pembelajaran penemuan terbimbing merupakan suatu cara penyampaian topik-topik matematika, hingga proses belajar memungkinkan siswa menemukan sendiri pola-pola atau struktur-struktur matematika melalui serentetan pengalaman-pengalaman belajar lampau. Keteranganketerangan yang harus dipelajari itu tidak disajikan di dalam bentuk akhir, siswa diwajibkan melakukan aktivitas mental sebelum keterangan yang dipelajari itu dapat dipahami. Dalam penyampaian materi pengajaran siswa tidak diberitahukan sebelumnya sehingga sebagian atau seluruhnya ditemukan sendiri.

Menurut Joyce \& Weil (1992) keuntungan metode penemuan adalah akan membantu siswa mengembangkan disiplin intelektual dan kebutuhan keterampilan untuk membangkitkan rasa ingin tahu dan mencari jawaban dari keingintahuannya.

Sintaks Model Pembelajaran Penemuan Terbimbing 


\begin{tabular}{|c|c|c|}
\hline Tahap & Tingkah Laku & Tingkah Laku Siswa \\
\hline $\begin{array}{l}\text { Tahap } 1 \\
\text { Observasi } \\
\text { untuk } \\
\text { menemuka } \\
\text { n masalah }\end{array}$ & $\begin{array}{l}\text { Guru menyajikan } \text { kejadian- } \\
\text { kejadian atau fenomena yang } \\
\text { memungkinkan } \quad \text { siswa } \\
\text { menemukan masalah }\end{array}$ & $\begin{array}{l}\text { Siswa mengembangkan } \\
\text { keterampilan berpikir } \\
\text { melalui observasi spesifik hingga } \\
\text { membuat inferensi } \\
\text { atau generalisasi }\end{array}$ \\
\hline $\begin{array}{l}\text { Tahap } 2 \\
\text { Merumuska } \\
\text { n masalah }\end{array}$ & $\begin{array}{lr}\text { Guru membimbing siswa } \\
\text { merumuskan masalah } \\
\text { penelitian r berdasarkan } \\
\text { kejadian dan fenomena yang } \\
\text { disajikannya }\end{array}$ & $\begin{array}{l}\text { Siswa merumuskan masalah yang akan } \\
\text { membawa siswa pada suatu persoalan } \\
\text { yang } \\
\text { mengandung teka-teki }\end{array}$ \\
\hline $\begin{array}{l}\text { Tahap } 3 \\
\text { Mengajuka } \\
\text { n hipotesis }\end{array}$ & $\begin{array}{l}\text { Guru membimbing siswa } \\
\text { untuk mengajukan hipotesis } \\
\text { terhadap } \\
\text { masalah yang telah } \\
\text { dirumuskannya. }\end{array}$ & $\begin{array}{l}\text { Siswa menetapkan jawaban sementara } \\
\text { atau lebih dikenal dengan istilah } \\
\text { hipotesis. }\end{array}$ \\
\hline $\begin{array}{l}\text { Tahap } 4 \\
\text { Merencana } \\
\text { kan } \\
\text { pemecahan } \\
\text { masalah } \\
\text { (melalui } \\
\text { eksperimen } \\
\text { atau cara } \\
\text { lain) }\end{array}$ & $\begin{array}{l}\text { Guru membimbing siswa } \\
\text { untuk merencanakan } \\
\text { pemecahan masalah, } \\
\text { membantu menyiapkan alat } \\
\text { dan bahan yang diperlukan dan } \\
\text { menyusun prosedur kerja yang } \\
\text { tepat. }\end{array}$ & $\begin{array}{l}\text { Siswa mencari informasi, } \\
\text { data, fakta yang diperlukan untuk } \\
\text { menjawab permasalahan/ hipotesis }\end{array}$ \\
\hline $\begin{array}{l}\text { Tahap 5 } \\
\text { Melaksana } \\
\text { kan } \\
\text { eksperimen } \\
\text { (atau cara } \\
\text { pemecahan } \\
\text { masalah } \\
\text { yang lain) }\end{array}$ & $\begin{array}{lrr}\text { Selama siswa } & \text { bekerja } & \text { guru } \\
\text { membimbing } & & \text { dan } \\
\text { memfasilitasi } & & \end{array}$ & $\begin{array}{l}\text { Siswa menguji kebenaran } \\
\text { jawaban sementara tersebut. Dugaan } \\
\text { jawaban ini tentu saja didasarkan } \\
\text { kepada data } \\
\text { yang telah diperoleh. }\end{array}$ \\
\hline $\begin{array}{l}\text { Tahap } 6 \\
\text { Melakukan } \\
\text { pengamata } \\
\text { n dan } \\
\text { pengumpul } \\
\text { an data. }\end{array}$ & $\begin{array}{l}\text { Guru membantu siswa } \\
\text { melakukan pengamatan } \\
\text { tentang hal-hal yang } \\
\text { penting dan membantu } \\
\text { mengumpulkandan } \\
\text { mengorganisasi data. }\end{array}$ & $\begin{array}{l}\text { keterangan yang dapat } \\
\text { digunakan untuk } \\
\text { memecahkan masalah } \\
\text { tersebut, misalnya dengan jalan } \\
\text { membaca buku-buku, } \\
\text { meneliti, bertanya } \\
\text { berdiskusi dan lain-lain }\end{array}$ \\
\hline $\begin{array}{l}\text { Tahap } 7 \\
\text { Analisi } \\
\text { Data }\end{array}$ & $\begin{array}{l}\text { Guru membantu riswa } \\
\text { menganalisis data supaya } \\
\text { menemukan sesuatu konsep }\end{array}$ & $\begin{array}{l}\text { Siswa menganalisis data } \\
\text { untuk menemukan sesuatu konsep. }\end{array}$ \\
\hline $\begin{array}{l}\text { Tahap } 8 \\
\text { Penarikan } \\
\text { kesimpulan } \\
\text { atau } \\
\text { penemuan }\end{array}$ & $\begin{array}{lrr}\text { Guru membimbing } & \text { siswa } \\
\text { mengambil } & \text { kesimpulan } \\
\text { berdasarkan data dan } & \text { data } \\
\text { menemukan sendiri konsep } \\
\text { yang ingin ditanamkan }\end{array}$ & $\begin{array}{l}\text { Secara berkelompok siswa menarik } \\
\text { kesimpulan, merumuskan kaidah, } \\
\text { prinsip, ide generalisasi atau konsep } \\
\text { berdasarkan data yang diperoleh }\end{array}$ \\
\hline
\end{tabular}


Menurut Markaban ( 2006), kelebihan metode penemuan terbimbing sebagai berikut: 1. Siswa dapat berpartisipasi aktif dalam pembelajaran yang disajikan; 2) menumbuhkan sekaligus menanamkan sikap inquiry (mencari-temukan); 3) mendukung kemampuan problem solving siswa; 4) Memberikan wahana interaksi antar siswa, maupun siswa dengan guru, dengan demikian siswa juga terlatih untuk menggunakan bahasa Indonesia yang baik dan benar; 5) materi yang dipelajari dapat mencapai tingkat kemampuan yang tinggi dan lebih lama membekas karena siswa dilibatkan dalam proses menemukannya.

Sementara itu kekurangannya adalah sebagai berikut a. Untuk materi tertentu, waktu yang tersita lebih lama; b. Tidak semua siswa dapat mengikuti pelajaran dengan metode penemuan terbimbing;c. Di lapangan, beberapa siswa masih terbiasa dan mudah mengerti dengan model ceramah; d. Tidak semua topik cocok disampaikan dengan metode penemuan terbimbing (Markaban, 2006).

A. Menggunakan turunan fungsi dalam perhitungan kecepatan dan percepatan

Turunan dari fungsi $\mathrm{y}=f(\mathrm{x})$ dapat ditulis dengan notasi Leibniz sebagai (Wirodikromo, 2007):

$$
\frac{a}{a} \text { atau } \frac{a}{a}
$$

Satu di antara penggunaan notasi Leibniz adalah untuk menganalisis hubungan antara panjang lintasan, kecepatan, percepatan,dan waktu dari sebuah benda yang bergerak.

1) Panjang Lintasan

Misalkan pada waktu $t$ detik, benda $P$ berada pada $f(t)$. Setelah $t$ detik kemudian, yaitu pada $(\mathrm{t}+\mathrm{t})$ detik, benda $P$ berada pada $f(\mathrm{t}+\mathrm{t})$. Dengan adanya pertambahan waktu sebesar $\mathrm{t}$ akan mengakibatkan pertambahan panjang lintasan sebesar $\mathrm{s}$, dan pertambahan panjang lintasan itu ditentukan oleh $\mathrm{s}=f(\mathrm{t}+\mathrm{t})-f(t)$. Dengan $\mathrm{s}=f(\mathrm{t})$ merupakan panjang lintasan (jarak) dalam meter.

$$
\begin{aligned}
& \mathrm{t}=\mathrm{t}_{2}-\mathrm{t}_{1}(\text { dalam satuan detik atau sekon) } \\
& \mathrm{s}=\mathrm{s}_{2}-\mathrm{s}_{1} \quad \text { (dalam satuan meter) }
\end{aligned}
$$

2) Kecepatan

Kecepatan rata-rata gerak benda $P$ dalam interval waktu t detik ditentukan oleh $\frac{a}{a}=\frac{I(\mathrm{t}+\Delta \mathrm{t})-I(t)}{\Delta \mathrm{t}}$ 
Kecepatan sesaat gerak benda $P$ pada waktu $t$ detik diperoleh dari proses pelimitan kecepatan rata-rata ketika t mendekati nilai nol. Dengan demikian, kecepatan sesaat itu ditentukan dengan proses limit sebagai

$\lim _{\Delta \rightarrow \square} \frac{\Delta \mathrm{s}}{\Delta \mathrm{t}}=\lim _{\Delta \rightarrow 0} \frac{f(\mathrm{t}+\Delta \mathrm{t})-I(t)}{\Delta \mathrm{t}}=\frac{a}{a}=\frac{a}{a}$

Kecepatan gerak dari suatu benda biasanya dilambangkan dengan $v(t)$ dalam satuan $\mathrm{m} /$ detik, sehingga hubungan antara panjang lintasan dan kecepatan dapat dituliskan sebagai berikut.

$\mathrm{V}(\mathrm{t})=\frac{a}{a}=\frac{a}{a}$

Kecepatan sesaat adalah laju perubahan panjang lintasan $s$ terhadap waktu $t$. Besar atau nilai skalar dari kecepatan pada waktut detik disebut laju dan didefinisikan sebagai nilai mutlak kecepatan. Jadi, Laju pada waktu $t=v(t)=\frac{a}{a}$. Hubungan $s$ dengan $v(\mathrm{t})$ dapat diungkapkan sebagai berikut.

Misalkan panjang lintasan $s$ sebagai fungsi waktu $T$ ditentukan oleh $\mathrm{s}=f(t)$ dalam interval waktu $T$ dan $\mathrm{v}(\mathrm{t})=\frac{a}{a}$ ada untuk setiap nilai $t$ dalam interval itu.

(a) Jika $\mathrm{v}(\mathrm{t})=\frac{a}{a}>0$ untuk $t \epsilon T$, maka $s$ naik pada interval $T$. Arti fisis dari $s$ naik adalah benda bergerak dengan nilai panjang lintasan $s$ yang semakin bertambah besar.

(b) Jika $\mathrm{v}(\mathrm{t})=\frac{a}{a}<0$ untuk $t \in T$, maka $s$ turun pada interval $T$. Arti fisis dari $s$ turun adalah benda bergerak dengan nilai panjang lintasan $s$ yang semakin berkurang.

(c) Jika $\mathrm{v}(\mathrm{t})=\frac{a}{a}=0$ untuk $T t$, maka $s$ stasioner pada interval $T$. Arti fisis dari $s$ stasioner adalah benda tidak bergerak atau diam sesaat.

3) Percepatan

Misalkan bahwa kecepatan gerak dari sebuah benda juga merupakan fungsi waktu atau $\mathrm{v}(\mathrm{t})$ berubah terhadap $t$. Laju perubahan terhadap kecepatan terhadap waktu disebut percepatan dari gerak benda tersebut. Percepatan pada waktu $t$ detik biasanya dilambangkan dengan $\mathrm{a}(\mathrm{t})$ dengan satuan $\mathrm{m} / \mathrm{detik}^{2}$. Dengan demikian, hubungan antara percepatan dengan kecepatan dan percepatan dengan panjang lintasan dapat ditentukan sebagai berikut.

$\mathrm{a}(\mathrm{t})=\frac{a}{a}=\frac{a}{a}\left(\frac{a}{a}\right)=\frac{a^{2} \mathrm{~s}}{a t^{2}}$, Selanjutnya, benda $\quad v \quad$ (bertambah atau berkurang) dapat ditentukan dengan mengamati tanda-tanda dari $v$ dan $a(t)$ secara bersamaan sebagai 
berikut. a) Jika $v$ dan $a(t)$ bertanda sama $(v>0$ dan $a(t)>0$ atau $v<0$ dan $a(t)<0)$, maka laju benda $v$ naik atau bertambah. b) Jika $v$ dan $a(t)$ berlainan tanda $(v>0$ dan $a(t)<0$ atau $v<0$ dan $a(t)>0$ ), maka laju benda $v$ turun atau berkurang.

Contoh. Sebuah benda bergerak sepanjang garis lurus. Panjang lintasan $s$ ditentukan oleh $\mathrm{s}=f(t)=t^{2}-6 t+4$ ( $s$ dalam meter dan $t$ dalam detik). a) Tentukan kecepatan benda pada waktu $t=1$ detik dan $t=6$ detik. b) Carilah nilai $t$ ketika kecepatan benda sama dengan nol. c) Tentukan pada interval $t$ mana kecepatan benda negatif dan pada interval $t$ mana kecepatan benda positif. d) Tentukan percepatan benda.

Jawab: a) Kecepatan $\mathrm{v}=\frac{a}{a}=2 \mathrm{t}-6$, kecepatan pada waktu $t=1$ detik adalah $v=2(1)-$ $6=-4 \mathrm{~m} /$ detik. kecepatan pada waktu $t=6$ detik adalah $v=2(6)-6=6 \mathrm{~m} /$ detik. b) Kecepatan benda sama dengan nol atau $v=0$, berarti: $2 t-6<0 \quad \mathrm{t}=3$, c) Kecepatan benda negatif atau $v<02 t-6<0 \quad \mathrm{t}=3$, Jadi, kecepatan benda negatif dalam interval $0<t<3$. kecepatan benda positif atau $v>0.2 t-6>0 \quad t>3$. Jadi, kecepatan benda positif dalam interval $t>3$. d) Percepatan benda $\frac{a}{a}=\frac{a^{2} \mathrm{~s}}{a}=2$. Jadi percepatan benda konstan (tidak berubah terhadap $t$ ) sebesar $a=2 \mathrm{~m} /$ detik $^{2}$.

B. Menggunakan turunan limit fungsi dalam perhitungan bentuk tak tentu limit fungsi

1) Bentuk-bentuk tak tentu $\frac{0}{0}$ dan $\frac{\omega}{w}$.

Definisi: bentuk-bentuk tak tentu (indeterminate form)

a) Jikalim $f(x)=0$ dan $\lim _{x \rightarrow u} g(x)=0$, maka bentuk $\lim _{x \rightarrow u} \frac{I(x)}{g(x)}$ dinamakan bentuk tak tentu $\frac{0}{0}$ dan $\frac{w}{w}$.

b) Jikalim $\operatorname{xim}_{x \rightarrow u} f(x)= \pm \infty$, maka bentuk $\lim _{x \rightarrow u} \frac{f(x)}{g(x)}$ dinamakan bentuk tak tentu $\frac{\omega}{u}$ pada $\mathrm{x}=\mathrm{a}$.

\section{2) Teorema L'Hopital}

Teknik perhitungan bentuk tak tentu limit fungsi dengan menggunakan turunan dikenal sebagai Teorema L'Hopital. Misalkan $f(x)$ dan $g(x)$ adalah fungsi-fungsi yang diferensiabel pada setiap titik dalam interval terbuka $I$.

Jika $g^{\prime}(\mathrm{x}) \neq 0$ untuk setiap $\mathrm{x} \neq u$ pada $I$ dan jika $\lim _{x \rightarrow u} \frac{I(x)}{g(x)}$ mempunyai bentuk tak tentu -

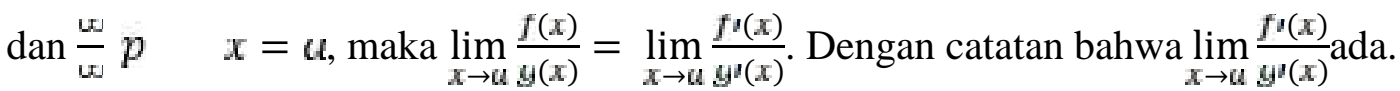


Dalam hal $\lim _{x \rightarrow u} \frac{f^{\prime}(x)}{g^{\prime}(x)}$ masih mempunyai bentuk tak tentu, makaproses perhitungan diteruskan dengan menggunakan turunan kedua $\lim _{x \rightarrow U} \frac{I(x)}{g(x)}=\lim _{x \rightarrow u} \frac{I^{r}(x)}{y^{r}(x)}=\ldots$. , demikian seterusnya sehingga diperoleh nilai limitnya.

Contoh. Hitunglah limit fungsi $\lim _{x \rightarrow 1} \frac{x^{2}-1}{x-1}$ dengan menggunakan teorema L'Hopital. Jawab Bentuk $\lim _{x \rightarrow 1} \frac{x^{2}-1}{x-1}$ merupakan bentuk tak tentu $\frac{\square}{\square}$ pada $\mathrm{x}=1$, sehingga limit tersebut dapat digitung dengan teorema L'Hopital. $\lim _{x \rightarrow 1} \frac{x^{2}-1}{x-1}=\lim _{x \rightarrow 1} \frac{2 x}{1}=2(1)=2$

C. Menggunakan turunan fungsi dalam menyelesaikan masalah yangberkaitan dengan nilai ekstrim

Penggunaan turunan fungsi dalam menyelesaikan masalah yang berkaitan dengan nilai ekstrim (nilai maksimum dan nilai minimum) sangatlah luas, seperti diperlihatkan pada beberapa ilustrasi masalah berikut ini.

1) Sebuah benda bergerak dengan panjang lintasan $s=20 t-5 t^{2}-5 t^{2}$ ( $s$ dalam meter dan $t$ dalam detik). Berapa panjang lintasan yang terbesar?

2) Sebuah proyek bangunan dapat diselesaikan dalam tempo $x$ hari dengan biaya proyek per hari sama dengan $\left(2 x+\frac{1}{x}-40\right)$ juta rupiah. Berapa biaya proyek yang minimum?

Masalah-masalah di atas memuat kata terbesar (maksimum atau yang searti dengan maksimum) dan kata terkecil (minimum atau yang searti dengan minimum) merupakan indikator bahwa masalah tersebut adalah karakteristik masalah yang model matematikanya berkaitan dengan nilai ekstrim fungsi. Setelah mampu mengidentifikasi bahwa karakteristik masalahnya terkait dengan nilai ekstrim fungsi, selanjutnya masalah tersebut dapat diselesaikan melalui langkah-langkah sebagai berikut.

Langkah-langkah pemecahan masalah yang berkaitan dengan problem nilai ekstrim.

1) Menetapkan besaran yang ada dalam masalah sebagai variabel (dilambangkan dengan huruf-huruf) untuk memperoleh hubungan atau ekspresi matematikanya.

2) Menetapkan rumus fungsi satu variabel yang merupakan model matematika dari masalah. 
3) Menentukan penyelesaian optimum (maksimum atau minimum) dari model matematika yang diperoleh pada langkah 2 .

4) Memberikan tafsiran terhadap hasil yang diperoleh pada langkah 3 disesuaikan dengan masalah semula.

Contoh. Sebuah besi beton dengan panjang $10 \mathrm{~m}$ dirancang berbentuk menyerupai huruf $U$ dengan cara membengkokkan bagian ujung-ujungnya. Jika $L$ menyatakan luas penampang dari bentuk rancangan itu (diperlihatkan daerah yang diraster), tentukan luas penampang yang maksimum. Jawab: Misalkan bagian ujung yang dibengkokkan masingmasing mempunyai panjang $x$, maka panjang bagian yang lurus adalah (10-2x). Luas penampang bentuk rancangan (bagianyang diraster) $L$ sebagai fungsi $x$ ditentukan sebagai berikut.

$\mathrm{L}(\mathrm{x})=(10-2 \mathrm{x})(\mathrm{x})=10 \mathrm{x}-2 \mathrm{x}^{2}$ Turunan pertama dan kedua dari $\mathrm{L}(\mathrm{x})$ terhadap $x$ berturutturut adalah $L^{\prime}(\mathrm{x})=10-4 \mathrm{x}$ dan $L^{\prime \prime}(\mathrm{x})=-4$, Syarat perlu ekstrim diperoleh dari $\mathrm{L}^{\prime}(\mathrm{x})=0$. $10-4 \mathrm{x}=0 \leftrightarrow \mathrm{x}=2 \frac{1}{2}$, Karena $L^{\prime \prime}(\mathrm{x})=-4$, maka berdasarkan uji turunan kedua akan terjadi nilai balik maksimum pada $x=2 \frac{1}{2}$ dan nilai balik maksimum itu adalah $L\left(2 \frac{1}{2}\right)=10\left(2 \frac{1}{2}\right)-$ $2\left(2 \frac{1}{2}\right)^{2} 2=12 \frac{1}{2}$. Jadi luas penampang yang maksimum itu adalah $\mathrm{L}=12 \frac{1}{2} \mathrm{~m}^{2}$ dicapai jika ujung-ujung kawat dibengkokkan sepanjang $\mathrm{x}=2 \frac{1}{2} \mathrm{~m}$.

\section{Kerangka Berfikir}

Metode pembelajaran penemuan terbimbing adalah suatu model pembelajaran yang berdasarkan pada filsafat konstruktivisme, sehingga dalam pembelajaran siswa dituntut aktif dan mandiri dalam mengumpulkan konsep yang akan digunakan dalam pemecahan suatu permasalahan. Oleh karena itu konsep yang ada pada suatu pokok bahasan akan tertanam kuat dalam ingatan siswa dan mereka akan terlatih dalam memecahkan suatu permasalahan matematika, khususnya dalam penelitian ini yaitu materi aplikasi turunan fungsi.

Model pembelajaran konvensional tidak menuntut keaktifan siswa, sehingga dalam pembelajaran siswa hanya sekedar mendengar, mencatat, dan kadang juga menyelesaikan soal berdasarkan contoh yang diberikan gurunya. Kebanyakan siswa hanya bisa menyelesaikan dalam persoalan yang sama dengan contoh dari gurunya, tetapi ketika soal sudah diubah sedikit, padahal konsepnya sama, mereka sudah tidak mampu 
menyelesaikan. Pada pembelajaran ini, konsep matematika khususnya materi aplikasi turunan fungsi tidak dapat tertanam dengan baik dalam diri siswa, karena kurangnya pengalaman dalam belajar. Oleh karena itu, pembelajaran dengan metode pembelajaran penemuan terbimbing dimungkinkan akan menghasilkan prestasi belajar yang lebih baik daripada pembelajaran dengan model konvensional.

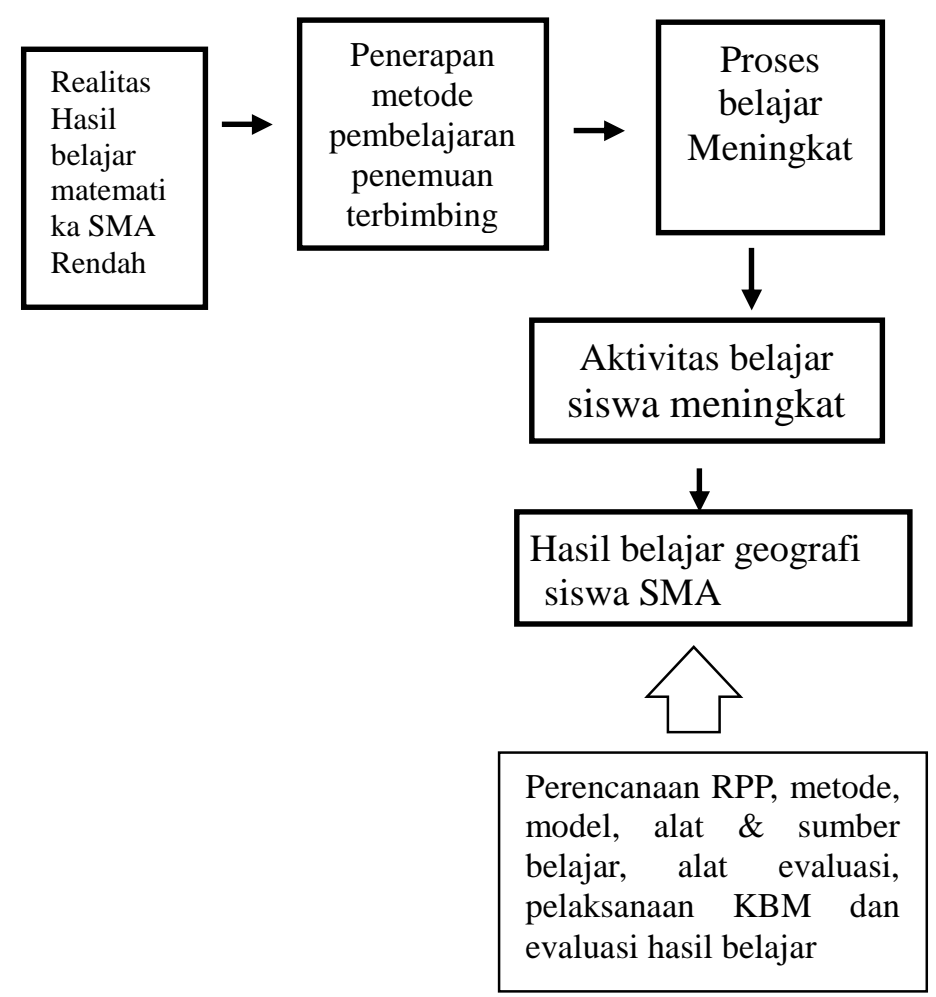

Dari berbagai uraian dan konsep berpikir di atas, maka manarik kiranya dilakukan penelitian melalui suatu tindakan kelas yang berjudul "Upaya Meningkatkan Prestasi Belajar Siswa pada Materi Aplikasi Turunan Fungsi Melalui Metode Pembelajaran Penemuan Terbimbing di Kelas XI MIPA-1 SMA Negeri 14 Banda Aceh”, dengan tujuan untuk mengetahui apakah prestasi belajar siswa kelas XI MIPA-1 SMA Negeri 14 Banda Aceh pada materi aplikasi turunan fungsi dapat ditingkatkan dengan penggunaan metode pembelajaran penemuan terbimbing?

\section{METODE PENELITIAN}

Penelitian dilaksanakan di SMA Negeri 14 Banda Aceh. Penelitian ini berlangsung pada semester 2 (Genap) tahun ajaran 2013/2014 yaitu bulan Februari - Mei 2014. Subjek penelitian dalam penelitian ini adalah siswa kelas XI MIPA-1 Tahun pelajaran 2013/2014 
dengan jumlah murid 32 siswa. Adapun teknik pengumpulan data yang digunakan dalam penelitian ini adalah:

Dokumentasi, dokumentasi adalah data yang sudah ada dan data tersebut diperlukan oleh peneliti dalam menyelesaikan penulisannya. Data-data tersebut bisa bersumber dari berbagai bahan cetakan seperti buku-buku, jurnal, surat kabar, foto-foto yang terkait dengan tema yang diteliti.

Tes, Tes dilakukan pada setiap akhir proses pembelajaran dengan menggunakan instrumen tes tertulis, soal yang diberikan sudah disiapkan sesuai dengan materi yang dilaksanakan pada setiaap akhir siklus I dan siklus II. Serta Observasi dilakukan dengan menggunakan lembaran isntrumen untuk melihat kegiatan siswa dalam proses pembelajaran diantaranya adalah aktivitas siswa pada saat melakukan diskusi Observasi dilakukan oleh guru kolaborasi sebagai observer pada saat proses belajar mengajar berlangsung.

\section{Teknik Analisa Data}

\section{Persentase Peningkatan Prestasi Belajar Siswa}

Analisis data untuk mengetahui kemampuan siswa dalam mencapai indikator dengan menerapkan metode demontrasi dengan statistik deskriptif (Sudijono, 2005:43) dengan katagori penilaian sebagai berikut :

Kategori Penilaian

\begin{tabular}{|l|c|}
\hline \multicolumn{1}{|c|}{ Persentase } & Kategori \\
\hline $80 \%<\mathrm{P} \leq 100 \%$ & Sangat Baik \\
$60 \%<\mathrm{P} \leq 80 \%$ & Baik \\
$40 \%<\mathrm{P} \leq 60 \%$ & Cukup \\
$20 \%<\mathrm{P} \leq 40 \%$ & Kurang \\
$0 \%<\mathrm{P} \leq 20 \%$ & Sangat Kurang \\
\hline
\end{tabular}

2. Observasi dengan analisis deskriptif berdasarkan hasil observasi aktifitas siswa dalam proses pembelajaran dan observasi PBM guru serta refleksi. Untuk menghitung prosentase pencapaian tiap siklus menggunakan rumus :

Teknik Penskoran :

$$
\text { Nilai }=\frac{\text { Skor yang diperoleh }}{\Sigma \text { Skor maksimum }} \times 100 \%
$$


Kriteria penilaian: Nilai baik : 80-100, Nilai cukup : 65-79 dan Nilai kurang

: 0-64. indikator keberhasilan yang diharapkan dalam penelitian ini adalah: a. Terjadi peningkatan hasil belajar siswa dari siklus 1 (satu) ke siklus berikutnya. b. Terjadi peningkatan aktivitas belajar siswa pada setiap siklus pada materi aplikasi fungsi

\section{Desain Penelitian}

Desain dalam penelitian ini mengacu pada desain penelitian yang diadaptasi dari model penelitian tindakan menurut Kemmis dan Taggart (Agustiani, 2010), sebagai berikut:

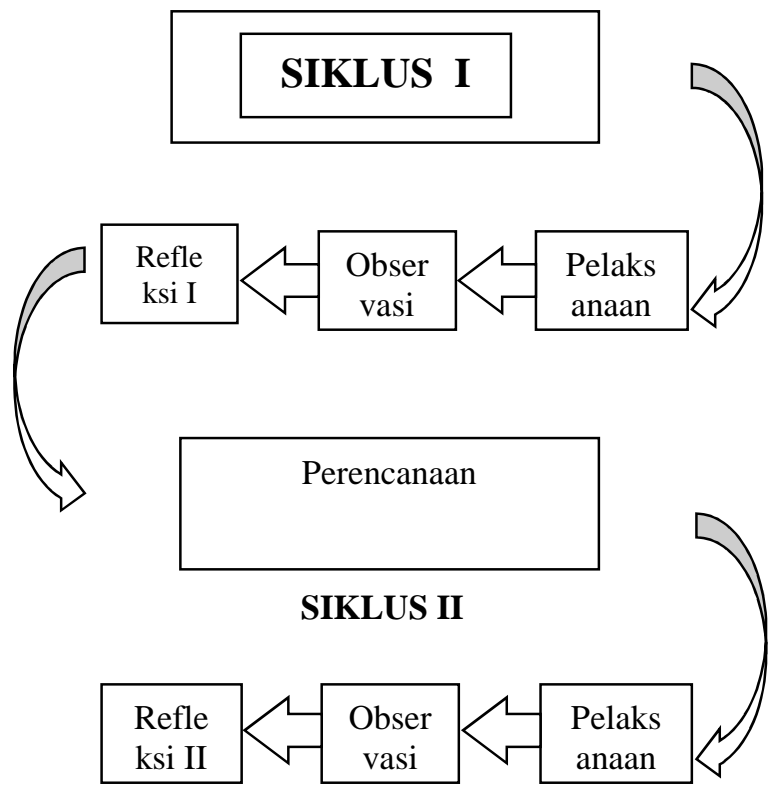

\section{Prosedur penelitian}

Penelitian ini dilakukan dengan menggunakan metode Penelitian Tindakan Kelas (PTK) yang terdiri dari 2 siklus. Adapun langkah-langkah dalam setiap siklus terdiri dari : a. Pengembangan plan (perencanaan), Pada tahap penyusunan rencana, penulis melakukan persiapan-persiapan terhadap pelaksanaan kegiatan meliputi: 1) menetapkan materi yang akan diajarkan; 2) menyusun Rancangan Pelaksanaan Pembelajaran (RPP); 3) menyusun instrument penilaian atau tes, b. Act (tindakan, Pada tahap ini dilakukan proses implementasi act (tindakan) dari Rancangan Pelaksanaan Pembelajaran (RPP) yang telah dirumuskan yang terdiri dari II siklus, c. Observer (pengamatan), Observasi dalam penelitian ini dilakukan pada saat kegiatan pembelajaran dilaksanakan. Observasi dilakukan oleh peneliti dan observer lainnya. 
Tindakan berikutnya adalah Reflect (perenungan), Refleksi dilakukan setelah selesai PBM pada siklus I, hasil observasi yang dilakukan observer didiskusikan bersama antara peneliti dengan guru observer tepat dijadikan sebagai pedoman terkait pelaksanaan PBM pada siklus I dan hasilnya dapat dijadikan pedoman untuk melakukan revisi RPP dan pelaksanaan PBM pada siklus II.

\section{Hasil Penelitian dan Pembahasan}

Hasil Penelitian

Analisis Data Penelitian Persiklus, pada siklus 1 dengan kegiatan : a. Tahap Perencanaan, Pada tahap ini peneliti mempersiapkan perangkat pembelajaran yang terdiri dari rencana pembelajaran siklus 1 , LKS , soal tes formatif dan alat-alat pengajaran yang mendukung. b. Tahap Kegiatan dan Pelaksanaan.

Pelaksanaan kegiatan belajar mengajar untuk siklus I dilaksanakan pada 12 sampai dengan 14 April 2014 di kelas XI MIPA-1 yang berjumlah siswa. Proses belajar mengajar mengacu pada rencana pelajaran yang telah dipersiapkan. c. Pengamatan (observasi), Pengamatan (observasi) dilaksanakan bersamaan dengan pelaksaaan belajar mengajar. Pada akhir proses belajar mengajar pada siklus I siswa diberi tes dengan tujuan untuk mengetahui tingkat keberhasilan siswa dalam proses belajar mengajar yang telah dilakukan.

Adapun data hasil penelitian pada siklus I sebagaimana yang telah diuraikan dengan langkah - langkah di atas adalah sebagai berikut:

Berdasarkan tabel di bawah diketahui hasil tes siswa berjumlah 32 orang, 17 (53\%) siswa tuntas dan 15 (47\%) siswa belum mencapai nilai tuntas, d. Refleksi, Pada siklus I, beberapa hal yang masih kurang diantaranya siswa masih kurang termotivasi dalam diskusi kelompok dan siswa masih enggan mengajukan pertanyaan. Kurang aktifnya siswa disebabkan karena siswa masih perlu beradaptasi dengan anggota kelompoknya. Setelah pelaksanaan tindakan I selesai dilaksanakan, diadakan tes siklus I untuk mengetahui tingkat penguasaan siswa terhadap materi Aplikasi turunan fungsi.

Tabel 4.1 Prestasi Belajar Siswa Siklus I 


\begin{tabular}{|c|c|c|}
\hline $\begin{array}{c}\text { Siswa } \\
\text { Menucut No. } \\
\text { Nbasn }\end{array}$ & Nilai & Ket \\
\hline 1 & 4) & Tidak Tunius \\
\hline 2 & 70 & Tuntas \\
\hline 3 & 35 & T:dak Tuntas \\
\hline 4 & 55 & Tidak Tuntas \\
\hline 5 & 70 & Tuntas \\
\hline 6 & 55 & Tuntes \\
\hline 7 & 45 & Tidak Tuntns \\
\hline 3 & 75 & Turitas \\
\hline 9 & 40 & Tidak Tuntas \\
\hline 1C & 5) & Iuntas \\
\hline 11 & 55 & Tuntas \\
\hline 12 & 45 & Tidak Tuntas \\
\hline 13 & 4) & Tinak Tuntas \\
\hline 14 & 70 & Tuntas \\
\hline 15 & 50) & Tidak Tuntas \\
\hline 16 & 70 & Tuntas \\
\hline 11 & 40 & lidak l untas \\
\hline 18 & 55 & Tuntas \\
\hline 15 & 45 & Tidak Tuntas \\
\hline
\end{tabular}

\begin{tabular}{|c|c|c|}
\hline 20 & 75 & Tuntas \\
\hline 21 & 45 & Tidak Tuntas \\
\hline 22 & 70 & Tuntas \\
\hline 23 & 70 & Tuntas \\
\hline 24 & 65 & Tuntas \\
\hline 25 & 40 & Tidak Tuntas \\
\hline 26 & 60 & Tidak Tuntas \\
\hline 27 & 65 & Tuntas \\
\hline 28 & 40 & Tidak Tuntas \\
\hline 29 & 70 & Tidak Tuntas \\
\hline 30 & 75 & Tuntas \\
\hline 31 & 45 & Tidak Tuntas \\
\hline 32 & 65 & Tuntas \\
\hline Jumlah Skor & 900 & \\
\hline $\begin{array}{l}\text { Rerata Skor } \\
\text { Tuntas } \\
\text { TidakTuntas }\end{array}$ & 57 & $17(53 \%)$ \\
& $15(45 \%)$ & \\
\hline
\end{tabular}

Berdasarkan hasil pembelajaran pada siklus I, masih perlu dilakukan perbaikan pembelajaran yaitu dengan melanjutkan ke tindakan II supaya target dari aspek kognitif dapat terpenuhi sehingga kompetensi pembelajaran dapat tercapai dengan baik.

Siklus II, sebagaimana langkah-langkah pada siklus I juga dilakukan pada siklus II ini meliputi : a. Tahap perencanaan, Pada tahap ini peneliti mempersiapkan perangkat pembelajaran yang terdiri dari rencana pelaksanaan pembelajaran (RPP), lembar kerja siswa (LKS) dan soal tes tertulis siklus II. b. Tahap pelaksanaan, Pada tahap ini peneliti menerapkan metode pembelajaran penemuan terbimbing dimana guru guru menyediakan data dan siswa diberi pertanyaan atau masalah untuk membantu mereka mencari jawaban, kesimpulan generalisasi dan solusi dalam proses belajar. Siklus I dilaksanakan pada tanggal 19 sampai dengan 21 April 2014. Langkah-langkah dalam pelaksanaan pembelajaran ini sesuai dengan RPP yang telah disusun dan diperbaiki sebelumnya. Untuk mengetahui pencapaian prestasi belajar siswa setelah dilaksanakan pembelajaran dengan menggunakan metode pembelajaran penemuan terbimbing pada siklus II, maka diberikan evaluasi kepada siswa.

Langkah berikutnya adalah c. Observasi, Berdasarkan hasil pengamatan pada pertemuan kedua, Secara keseluruhan pembelajaran berjalan dengan baik. Siswa antusias dalam menyelesaikan masalah saat diskusi. Siswa juga sudah berani bertanya kepada guru apabila ada hal yang kurang dimengerti serta mempresentasikan hasil diskusi.

Data hasil prestasi belajar siswa pada siklus II adalah sebagai berikut: 
Tabel 4.2 Pretasi Belajar Siswa Siklus II

\begin{tabular}{|c|c|c|}
$\begin{array}{c}\text { Siswa } \\
\text { Menurut } \\
\text { No. Absen }\end{array}$ & Nilai & Ket \\
\hline 1 & 80 & Tinntas \\
\hline 2 & 80 & Tuntas \\
\hline 3 & 65 & Tuntas \\
\hline 4 & 70 & Tuntas \\
\hline 5 & 95 & Tuntass \\
\hline 6 & 65 & Tunilas \\
\hline 7 & 55 & Tidak \\
\hline 8 & 90 & $\begin{array}{c}\text { Tuntas } \\
\text { Tuntas }\end{array}$ \\
\hline 9 & 60 & Tidak \\
\hline 10 & 10 & Tuntas \\
\hline 11 & 70 & Tuntas \\
\hline 17 & 65 & Tuntas \\
\hline 13 & 80 & Tuntas \\
\hline 14 & 80 & Tuntas \\
\hline 15 & 75 & Tunilas \\
\hline 16 & 75 & Tuntas \\
\hline 17 & 65 & Tuntas \\
\hline 18 & 65 & Tuntas \\
\hline 19 & 65 & Tuntas \\
\hline 20 & 85 & Tuntas \\
\hline & & \\
\hline
\end{tabular}

\begin{tabular}{|c|c|c|}
\hline 21 & 65 & Tuntas \\
\hline 22 & 75 & Tuntas \\
\hline 23 & 75 & Tuntas \\
\hline 24 & 80 & Tuntas \\
\hline 25 & 55 & $\begin{array}{c}\text { Tidak } \\
\text { Tuntas }\end{array}$ \\
\hline 26 & 70 & Tuntas \\
\hline 27 & 65 & Tuntas \\
\hline 28 & 50 & $\begin{array}{c}\text { Tidak } \\
\text { Tuntas }\end{array}$ \\
\hline 29 & 75 & Tuntas \\
\hline 30 & 90 & Tuntas \\
\hline 31 & 65 & Tuntas \\
\hline 32 & 75 & Tuntas \\
\hline $\begin{array}{c}\text { Jumlah } \\
\text { Skor }\end{array}$ & 2295 & \\
\hline $\begin{array}{l}\text { Rerata Skor } \\
\text { Tuntas } \\
\text { TidakTuntas }\end{array}$ & 71 & $(87,5 \%)$ \\
\hline
\end{tabular}

Berdasarkan data dalam tabel tersebut dapat kita ketahui bahwa ketuntasan klasikal prestasi belajar siswa di kelas XI MIPA-1 SMA Negeri 14 Banda Aceh pada materi aplikasi turunan fungsi telah tercapai. Yaitu 87,5\% dengan frekuensi siswa yang tuntas mencapai 28 siswa dan skor rata-rata siswa mencapai 71. Nilai tersebut telah melebihi kriteria keberhasilan dalam penelitian ini yaitu $85 \%$ untuk ketuntasan klasikal. Berdasarkan hasil penelitian tersebut penelitian ini telah dapat dihentikan.

d. Refleksi, Pembelajaran dengan penerapan metode penemuan terbimbing pada materi aplikasi turunan fungsi pada tindakan II diperoleh hasil yang lebih baik dibandingkan tindakan I

\section{Pembahasan}

\section{Pembahasan Antar Siklus}

Dari hasil penelitian, diperoleh bahwa metode pembelajaran penemuan terbimbing memiliki dampak positif dalam meningkatkan prestasi belajar siswa pada materi aplikasi turunan fungsi. Hal ini dapat dilihat dari semakin meningkatnya pemahaman siswa terhadap materi yang disampaikan guru, yakni ketuntasan belajar meningkat dari 53\% atau 17 siswa yang tuntas, meningkat menjadi 87,5\% atau 28 siswa yang tuntas pada siklus II. Hal ini disebabkan karena pada metode pembelajaran 
penemuan terbimbing siswa ditekankan pada pengalaman belajar secara langsung melalui kegiatan penyelidikan, menemukan konsep dan kemudian menerapkan konsep yang telah diperoleh dalam kehidupan sehari-hari, siswa didorong untuk berpikir kritis, menganalisis sendiri, sehingga dapat menemukan konsep atau prinsip umum berdasarkan bahan/data yang telah disediakan guru. Akhirnya berimbas pada meningkatnya prestasi belajar siswa.

Data prestasi belajar siswa antar siklus dapat dilihat pada tabel di bawah ini.

Tabel 4.4 Data Prestasi Belajar Siswa Antar Siklus

\begin{tabular}{|l|c|c|c|}
\hline \multirow{2}{*}{$\begin{array}{l}\text { Kegiata } \\
\text { n }\end{array}$} & \multicolumn{2}{|c|}{$\begin{array}{c}\text { Perolehan Hasil } \\
\text { Belajar (Skor 70) }\end{array}$} & \multirow{2}{*}{ Ketuntas } \\
\cline { 2 - 3 } & $\begin{array}{c}\text { Nilai } \\
\text { 65 ke } \\
\text { Atas }\end{array}$ & $\begin{array}{c}\text { Nilai 64 } \\
\text { ke } \\
\text { bawah }\end{array}$ & \\
\hline Siklus I & 17 & 15 & 53 \\
\hline Siklus II & 28 & 4 & 87,5 \\
\hline
\end{tabular}

\section{KESIMPULAN}

Dari hasil kegiatan pembelajaran yang telah dilakukan selama dua siklus dan berdasarkan seluruh pembahasan serta analisis yang telah dilakukan dapat disimpulkan bahwa: pembelajaran dengan menggunakan metode pembelajaran penemuan terbimbing memiliki dampak positif dalam meningkatkan prestasi belajar siswa kelas XI MIPA-1 SMA Negeri 14 Banda Aceh pada materi aplikasi turunan fungsi, ditandai dengan peningkatan ketuntasan belajar siswa dalam setiap siklus, yaitu siklus I (53\%) dan siklus II $(87,5 \%)$ dengan kategori sangat baik. Berdasarkan hasil penelitian tersebut dapat kita simpulkan pelaksanakan metode pembelajaran penemuan terbimbing didasari pada penyusunan persiapan yang cukup matang, dan memilih topik yang sesuai untuk diterapkan dengan metode pembelajaran penemuan terbimbing dalam proses pembelajara sehingga diperoleh hasil yang optimal.

\section{Daftar Pustaka}

- Djamarah, B. S. 2008. Psikologi Belajar. Jakarta: Rineka Cipta.

- Hamalik, O. 2001. Proses Belajar Mengajar. Bandung : Bumi Aksara.

- Hudojo, H. 2003. Pengembangan Kurikulum dan Pembelajaran Matematika. Malang: UM PRESS. 
- Jailani, J., Abubakar, A. and Anwar, A., 2018. Implementasi Pendekatan Science Technology Society (Sts) Pada Materi Pokok Lingkungan Hidup Sebagai Upaya Peningkatanlife Skill Siswa. JURNAL SERAMBI ILMU, 30(2), pp.132-142.

- Yana, S.Y.S., 2018. Pendidikan Berbasis Kompetensi Pada Sekolah Menengah Kejuruan (SMK)(Pembelajaran Terhadap Pengendalian Mutu Produk Roti Nusa Indah Bakery). JURNAL SERAMBI ILMU, 17(2), pp.125-130.

- Joyce \& Weil. 1992. Models of Teaching, Second Edition. New Jersey : Prentice-Hall.

- Markaban. 2006. Model Penemuan Terbimbing pada Pembelajaran Matematika SMK. Yokyakarta: Pusat Pengembangan dan Pemberdayaan Pendidik dan Tenaga Kependidikan Matematika.

- Slameto. 2003. Belajar dan Faktor-Faktor yang Mempengaruhinya. Jakarta: Rineka Cipta.

- Nurlaili, N., 2016. Penerapan Model Pembelajaran Contextual Teaching And Learning (Ctl) Dalam Meningkatkan Hasil Belajar Siswa Pada Mata Pelajaran Geografi Kelas Xi. 1 Is Di Sma Negeri 5 Banda Aceh. JURNAL SERAMBI ILMU, 27(2).

- Sudijono, A. 2005. Pengantar Statistik Pendidikan. Jakarta: Rajawali Press.

- Zainuddin, Z., 2018. Peningkatan Kemampuan Menguasai Materi Pembelajaran Melalui Pengembangan Keprofesian Berkelanjutan (Pkb) Guru Kelas Di Uptd Makmur Kabupaten Bireuen. JURNAL SERAMBI ILMU, 30(1), pp.24-38.

- Suprayekti. 2003. Interaksi Belajar Mengajar. Jakarta. Direktorat Tenaga Kependidikan, Dikdasmen, Depdiknas.

- Roslina, R., Ainun, N.A.N. and Setiawati, S.S.S., 2018. Pembelajaran Pemecahan Masalah Pada Materi Bangun Datar Pada Siswa Sd. JURNAL SERAMBI ILMU, 30(1), pp.39-45.

- Suryobroto. 2002. Proses Belajar Mengajar Di Sekolah. Jakarta : Rineka Cipta .

- Sutrisno, H 2007. Metodologi Research Penulisan Paper, skripsi, Thesis dan Disertasi Yogyakarta: Yayasan penerbitan fakultas psikologi UGM.

- Irwansyah, I., Harus, C.Z.H.C.Z. and Ibrahim, S.I.S., 2018. Manajemen Kelas Dalam Proses Pembelajaran Sejarah Di Sman 8 Kota Banda Aceh. JURNAL SERAMBI ILMU, 17(2), pp.85-91.

- Rezeki, S.R.S., AR, M.A.M. and Harun, C.Z.H.C.Z., 2018. Manajemen Pembelajaran Pendidikan Dan Pelatihan Prajabatan Pada Bkpp Aceh. JURNAL SERAMBI ILMU, 13(2), pp.51-124. 
- Sudijono, A. 2005. Pengantar Statistik Pendidikan. Jakarta: Raja Grafindo Persada.

- Suharsimi Arikunto. 2002. Dasar-Dasar Evaluasi Pendidikan (edisi revisi) Jakarta: Bumi Aksara

- Saiful Sagala. 2006. Konsep dan Makna Pembelajaran. Bandung: CV. Alfabeta

- Zakiah Daradjat, dkk, 1992. Ilmu Pendidikan Islam, Jakarta : Bumi Aksara

- Zuhairini,dkk. 1983. Metode Khusus Pendidikan Agama, Surabaya: Usaha Nasional. 